\title{
DIY John Curtin: Uncertain Futures for Heritage and Citizenship in the Era of Digital Friends and Foes
}

\author{
John Hartley, ${ }^{1}$ Niall Lucy, Robert Briggs \\ Curtin University, Australia
}

\section{Citation}

Hartley, J., N. Lucy, and R. Briggs (2013) 'DIY John Curtin: Uncertain futures for heritage and citizenship in the era of digital friends and foes'. International Journal of Cultural Studies, 16 (6): 557-77.

\begin{abstract}
This paper introduces some of the problems confronting the popularisation of national, civic and cultural heritage in the era of complex digital systems and social networks. Taking contemporary knowledge of John Curtin (Australia's wartime PM) as its point of departure, the discussion explores some of the broader transformations to the conditions of citizenship, communication, heritage and knowledge production, and considers their implications for civic education and the uses of archives. In a novel thought experiment, the paper explores some ways in which the figure of 'John Curtin' may be repurposed and reinvented for a new kind of DIY civic education based on user-led innovation.
\end{abstract}

Keywords: John Curtin, civic education, national identity, Do-It-Yourself (DIY) culture, digital archives, citizenship

\footnotetext{
${ }^{1}$ Corresponding author: John Hartley, Faculty of Humanities, Curtin University, GPO Box U1987, Perth 6845, Australia. Email: john.a.hartley@ curtin.edu.au
} 


\section{Searching, Not Findings}

No one visiting the Australian War Memorial in Canberra can fail to be drawn in by the pathos of the extraordinary dioramas on display, depicting far-flung battle scenes (Hewitt 1984; Winter 2012). ${ }^{1}$ Designed as dramatic re-enactments of historical events, the dioramas functioned originally not as historical artefacts in themselves, but simply as a storytelling device, a mode of exhibition, for bringing to life the history of nationhood (friends versus foes) for citizen-visitors, or citizen-audiences. Today, though, not only do they stage the past; they belong to it, as fascinating curiosities of interactive media from a time before television let alone the Internet. But what if, in retrospect, the dioramas were seen to gesture not to the past at all, but to the future of national heritage itself - as a curatorial or archival problem? We ask this not as historians but as media scholars, in response to a particular event in our own workplace: the imminent relocation of an exhibition of materials relating to the life, times and works of Australia's wartime prime minister, John Curtin, from the gallery in which the collection is presently held at Curtin University in Perth (Western Australia). The gallery space is earmarked for transformation into a 'digital laboratory' for creative arts and other purposes. Naturally, the question arose as to whether - and how - the Curtin materials themselves might be transformed into a digital archive available for experiment and innovation.

That has led to a wider question, of what the John Curtin 'archive' (in total, not only at Curtin University) actually comprises, what uses it might be put to in the digital age ... and by whom. This article is prompted by these questions. Unlike most research papers, this one is devoted to 'searchings' rather than to 'findings'. It illustrates the genesis of a humanities research project and what's at stake in pursuing it. We don't 
seek to produce general conclusions - at least, not about the meaning of John Curtin but instead want to draw together some observations about recent, large-scale transformations in communication and politics in order to consider their implications for the work (professional and informal) of popularising knowledge about political and cultural history. The paper is in the nature of a 'thought experiment', reporting on the construction rather than the solution of a problem. Yet the discussion may point the way not just towards a future research agenda, but also towards possible strategies for making, teaching, exhibiting and applying history, particularly in the context of civic education. Our purpose is to clarify what is at stake in propagating citizenly knowledge and activities across whole populations; so while John Curtin certainly matters, we don't want to pass judgement on his particular historical significance. Rather, we want to contribute to the scholarship of how such significance (or knowledge of it) can be recreated and distributed in the era of social media, social networks, and consumer-created content. At the heart of the project lies the problem of expertise in knowledge systems, where traditional relations between 'knowing' professional producers (including historians or media researchers) and supposedly ignorant consumers have been thrown into crisis, if not thrown out of the window.

\section{A Problem of Significance}

Who is John Curtin? How do we know? As a modern, multicultural, migrant, global community, why should we care? And what are 'we' (including, say, school-age students, new citizens or Indigenous Australians) able to do for ourselves in order to find out or, more important, how to relate what we do care about to any meaningfulness that might emerge from the signifier 'John Curtin'? These are our central questions, but they are not primarily historical or heritage ones; their concern 
with agency, relationship and meaningfulness in the here and now speaks to an 'open future' for new citizens. Australia is a country with an increasingly diverse population, with or without citizenship, who may know little about how Australian democracy and its role in the wider world has evolved - and who was responsible, under what pressures. Such unknowingness is not confined to migrants and children, however. There is a sense in which all citizens are new, because citizenship itself is a dynamic, evolving concept that has been reconfigured in relation to contemporary communications media (Miller 2006; Hartley 2012 ch6), and by the expansion of commercial agencies into institutions and spaces that formerly constituted the public sector and the public sphere (Peters 2004). Indeed, how could citizenship in the digital age be anything other than a 'new' concept compared with earlier periods (Dahlgren $2000) ?^{2}$

There is therefore a synchronic, technological and institutional aspect to citizenship how far does it reach into the population, both formally and informally, through what agencies? And there is a diachronic or historical dimension, as direct knowledge of a given era recedes. Either way, the need for effective civic education - official and informal - increases. Frank Lowy, co-founder of the Westfield shopping centre group and prominent migrant, recognised this in his 2012 inaugural Multicultural Council of Australia Lecture:

As a visitor to the US, I have often admired how it encourages new arrivals to make its institutions the focus of loyalty. They have developed a civic faith built on their constitution, bill of rights and their flag. Of course, despite sharing many things in common, Australia is not America. But we 
can still develop a more muscular approach to our civic life, in an Australian way, a reinvigorated focus on civics education (Lowy 2012). Few historical figures could better illustrate the 'many things in common' that Australia shares with the USA than John Curtin. It was as wartime leader that he announced, in 1941, what became Australia's declaration of independence-of-action from the Imperial motherland: 'Without any inhibitions of any kind, I make it quite clear that Australia looks to America, free of any pangs as to our traditional links of kinship with the United Kingdom' (Curtin 1941).

Curtin took the decisive action; but the necessary elements of closer Australia-US relations (strategic, economic and cultural) had been building for a generation or more before he took up residence in The Lodge. As one of his predecessors, conservative prime minister Stanley Bruce, had put it in the mid-1920s: 'Serious-minded Australians' are beginning to wonder 'whether we are safe in depending solely on the British navy' (The Times, 10 June 1925, cited in Dutt 1936: 234-5). Bruce thought Australians had a natural sympathy with Americans, as well as sharing the common interests of settler societies: 'They [Australians] felt, too, that when America struck the blow for liberty in the eighteenth century, she struck a blow for the Dominions today' (The Times, 12 November 1925, cited in Dutt 1936: 236; see also 224-6, 235-8).

Curtin's 1941 declaration is still seen as a significant rhetorical shift that opened Australian nationhood to new possibilities and another kind of future. Former PM Paul Keating put it bluntly:

Curtin was a wartime Prime Minister and the dominant issue of his Prime Ministership was the salvation of his country. Something which 
he accomplished by adapting himself and the country rapidly to changing events and circumstances. (Keating, 2009)

If, as Lowy and Keating both seem to suggest, that move holds important lessons for contemporary Australia and its future in the region, how are such lessons going to reach those who may have most need to learn them, but least motivation? What stories (etc.) might arouse popular interest in Curtin? ${ }^{3}$ How might what Curtin means then impose upon actual or aspiring citizens certain ethical or caring obligations (e.g. defence of democracy) as well as rights (e.g. tolerance of their own difference)? If citizens are to be future-facing agents of change (like Curtin), how can knowledge (about Curtin) be parlayed into action?

\section{Friends, Foes and Facebook}

The civic realm was once tied directly to the geo-political domain of citizens, who belonged originally to particular cities, and thereafter, by metaphoric extension, to nations. Citizenship gained revolutionary status in the American and French revolutions of the eighteenth century, and developed, with the concept of modern nationhood, on the back of industrial technologies, such that a nation could be understood as an economic rather than an ethnic population. But in the era of global digital networks, markets and culture, it might be said that the modern notion of nationhood is all but obsolete. What's left of 'the nation' for its citizens? It is the unit of political and legal jurisdiction, taxation and minor ceremonial 'affect' (civic and sporting). While many of its modern markers - the national airline, national broadcaster, university, museum, etc. - survive (albeit frequently privatized), the epithet has ceased to exert a binding force on all within its ethno-territorial reach in the era of globalised network culture. Even national armed forces are only that in 
name - the ADF (Australian Defence Force) is no longer a citizen army and 'the military' plays no role in most citizens' lives except as an employment agency (its website is called www.defencejobs.gov.au). Thus the concept of a 'national curriculum' for schools may be anachronistic even before it is implemented, posing problems for civic as well as other types of education, and betraying a centralizing purpose (favouring Federal over State control of education systems) rather than any compelling sense of a unified national identity that all school-students need to share. Having said that, the concept of the nation remains forceful politically, notably in relation to migration policy and the treatment of asylum-seekers. So-called 'illegal' arrivals by boat have been cast in the role of 'invaders' in partisan electoral politics over the past two decades (Hartley \& Green 2006), recasting refugees as enemies. ${ }^{4}$ This harks back to the political philosophy of Carl Schmitt (2006), who notoriously argued in the 1930s that there is no politics without 'foes'.

But as citizenship is abstracted from place, how can national borders and the distinction between 'friend' and 'foe' be experienced as anything other than arbitrary? For today's so-called digital natives, indeed, a 'friend' isn't someone defined in opposition to an 'enemy'. A friend is anyone with whom you are networked on Facebook, a person (or group, brand, or institution) who could come from anywhere in the world and not simply from the neighbourhood, the city or country in which you live. Yet before this is taken to indicate that Facebook is responsible for re-signifying the meaning of 'friend', emptying its 'real' meaning and sundering it from a supposed original point of reference, we should recall (with Schmitt) that the word 'friend' once referred to "the friend of blood, the consanguine parent or again "the parent by alliance" through marriage, oath of fraternity, adoption or other corresponding 
institutions' (Schmitt 2006: 104). Prior to Facebook and other social media, a friend was someone to whom you were bonded directly, according to felt personal interests, or indirectly according to supposedly shared national interests. But this was already a metaphoric extension of an earlier meaning: someone to whom you were related as a family member, by blood or law. It wasn't Facebook that changed the meaning of 'friend'; it was modernity, via the industrial revolution.

Schmitt wanted friendship to be coterminous with citizenship, such that for him a nation was akin to a family ('kith and kin'). Citizenship was familial; a shade of meaning still invoked today at times of war or national disaster, when the nation is called on by its political leaders to mourn the tragic loss of 'our' 'sons' or 'daughters'. A shift from citizenship-as-friendship to citizenship-as-Facebook is thus consistent with the modern, metaphoric shift in the meaning of citizenship itself - from actual city to abstract nation. What may seem false or disingenuous about Facebook 'citizenship' is its territorial abstraction: not, what is Facebook; but rather, where 'is' Facebook? Yet 'Australia' and other nation-states are not reducible to a geo-physical place either. They are a product (an 'imagined' one: Anderson 1991) of intangible elements including social knowledge, cultural know-how and civic education. What happens to ideals or myths of national belonging in an era of increasingly global online interaction? If, let's say in the age before social media, your friends were your fellow-citizens, then national friendship may be distinguished from the digital type simply through choice. Online, individuals may choose group membership (friendship), and 'communities of affect' (Hebdige 1989: 90) may be created around the simple action of 'liking' according to affinity, via shared interests in music, politics, movies or, in current vernacular, whatever. ${ }^{6}$ 
Meanwhile, real individuals are co-opted into group membership (citizenship) on behalf of interests they are represented to share, from newspaper editorials to military adventures, but which, in many cases, they may actively oppose. Online friendship is not obligation-free, but it is not determined by a legal system, in contrast to the national allegiance required of citizens, who risk a charge of treason if they transgress it. Even here, however, the cases of David Hicks (Hicks 2010) and Julian Assange show that legal jeopardy already exceeds the nation-state. Assange, an Australian citizen, is holed up indefinitely (as we write) in the Ecuadorian embassy in Britain, seeking asylum from $U S$ prosecution by avoiding extradition to Sweden. Sorting out friend from foe in this environment is not a matter of ethno-territorial heritage.

Online friendship may take many chosen and therefore personal forms, none of which needs to comply with an ideal of intimate, face-to-face friendship. Even so, online friendship can be more authentic, proximate, intimate and real than representative friendship as defined by legal citizenship. Language differences aside (and Google Translate is making even these easier to negotiate), online user-citizens in Perth, say, have no more necessary connection or affinity with users in Brisbane than with counterparts in Jakarta or Beijing. Thus it is experientially if not juridically the case that we no longer have nations; we have networks.

If reading the morning newspaper was judged by Hegel in the nineteenth century to be a responsibility of the modern subject, and by Benedict Anderson in the twentieth to be constitutive of citizenship, we may say that the twenty-first century equivalent 
inheres in a responsibility to engage with social media (Papacharissi 2010). As we write, for instance, commercial news outlets in Australia find only marginal newsworthiness in the latest Israeli strikes against Hamas in Gaza; and yet our Twitter feeds are full of information (some of it first-hand) and comment on that subject. If old media claim to represent the common interests of Australian reader-citizens, how should we account for the fact that social media, generated by those same readercitizens, but now as user-producers, are preoccupied with topics deemed more or less unnewsworthy by 'national' media institutions? This mismatch between modern (representative) and contemporary (productive) media raises a question that we believe has not been asked: can - and how can - significant figures in the former system (John Curtin, say) make the jump to the current one?

\section{Active Inheritance}

Some people have evidently concluded that the jump has not been made, and the population of young Australians is not being reached, even via formal education. Former PM John Howard, for instance, lambasted the draft national curriculum, in the 2012 inaugural Sir Paul Hasluck lecture in Perth:

There is much about the [draft history] curriculum that I find unbalanced and in some cases quite bizarre. An illustration of the bizarre is to be found in the Year 10 curriculum. In it, students are required to do what is called an in-depth study of one of three aspects of globalisation from 1945 to today: the options are popular culture, environmental movements or mass migration movements (Howard 2012). ${ }^{7}$ 
Or, as the headline in The Australian colourfully put it, 'Bizarre history curriculum studies Kylie not capitalism'. Howard himself added: 'Those who wrote this curriculum, in their infinite wisdom, believed that AC/DC and Kylie Minogue are more important [than economic factors] to an understanding of the globalising world since 1945,' and regretted the 'retreat from self-belief in Western civilisation. ${ }^{8}$ Here was an open reference to the supposed effects of cultural studies on the teaching of history; a familiar topic from the so-called 'history wars' of the 1990s and early 2000s in Australia. Doubtless, neither Howard nor the sub-editor responsible for the headline would have had any time for the lessons for popular democracy, or what we might call 'critical civics', of co-author Hartley's work on Kylie Minogue. Far from seeking to replace 'capitalism studies' with 'Kylie studies', such work seeks to show how they may be mutually illuminating, especially for denizens of popular culture who don't encounter formal economic history (Hartley 1992: 218; 1996: 147-9, 17195).

Border-control skirmishes and scandals among experts, over the question of who owns which disciplinary objects and methods, exert little sway on popular understandings of knowledge. Indeed, coming back to Kylie, one might easily say of celebrity culture what Germaine Greer (2001) once said of Big Brother: 'Reality television is not the end of civilisation as we know it; it $i$ civilisation as we know it'. Studying 'civilisation as we know it' is defensible; linking it with the past is also desirable. But recruiting the past to serve just one interpretation of 'Western civilisation', to be taught compulsorily in schools, is surely mistaken: it risks losing the very constituency it most needs to recruit. 
In an era when - despite Howard's discomfort - people know more about Kylie than Curtin, what should civic education do? One way to tackle it is to bring important achievements to life. John Curtin's were second to none: 'the salvation of his country', according to Keating; and his decisive role in the shift from linemanagement by Britain to independent engagement with the USA and the AsiaPacific region. These achievements were won under pressure of war, even while looking forward to an 'open future', which for Curtin and his Government included active involvement in establishing the United Nations, demonstrating a commitment to internationalism as much as to nationalism. ${ }^{9,10}$

As the generation who were coeval with him passes away or leaves the workforce, 'John Curtin' becomes something other than a man with a story: he becomes data. Direct or contemporaneous knowledge sediments out of the civic realm into layers of 'repository'. For this-century citizens, John Curtin is an archival problem. And the question about who he is could equally well be asked of the nation - 'What is Australia?' - since he is part of the answer, even though many young Australians may never have heard of him. Thus, national identity is partly an archival problem, too not simply of storage, but of active interpretation and active inheritance. To be known, data must be kept, sorted, found, manipulated (made anew) and distributed (recreated in the minds of knowing subjects) and only then can questions come alive, to be resolved for the time being (they remain to be actively interpreted again by future generations of user-citizen-producers). Civic inheritance is not a cultural commodity willed intact to the future by information-rich uncles; it is a contemporary cultural activity. The past bequeaths only what present-day agents actively select, interpret and adapt for particular purposes. 
This activity results in Raymond Williams' classic observation in The Long Revolution (1961) of three levels of culture, where 'lived' (contemporary) culture and recorded or 'period' culture are linked by what he calls the 'selective tradition'. Williams later politicised this typology by introducing the foe-creating idea of 'dominant' as opposed to 'residual' (past) and 'emergent' (future) culture, where the 'selective tradition' is firmly understood as a process of selecting a past that benefits currently hegemonic groups. We selectively inherit not just this or that aspect of historical tradition, but also the very means by which we may bear witness to our heritage (Derrida 1994: 54). The rules of selection are themselves subject to negotiation and active interpretation, and so too are the ideals, techniques and even media of civic education. It is not necessary to endorse Williams' specific political agenda to appreciate his point that the past serves the present, and that the agents of that service are alive now, actively selecting. Sometimes, as with Howard and The Australian, that process takes the form of an equally foe-creating contest over the rules for selection. However, even shorn of partisan politics, a problem remains: how might Curtin jump from 'residual' to 'emergent' culture, and how can the 'selective tradition' (via civic education) assist in that process, preferably avoiding the pitfalls of 'dominant ideology'?

Debates over the rules for selection are usually confined to academic journals (like this one) or, at their most public, to the opinion pages of broadsheet newspapers. But the process itself belongs to larger-scale and impersonal systems, which are not so easily controlled by knowledgeable expertise. Thus the problem of the archival nature of the past extends to the entire apparatus of heritage, the technical and institutional 
conditions on the basis of which the very question of Curtin's political-historical significance may even be asked, let alone addressed.

\section{The Public in the Archive}

National and cultural heritage have been the preserve of those institutions now called the 'GLAM' sector (Galleries, Libraries, Archives, Museums). In the era of global digital connectivity, this entire sector is also experiencing rapid and dynamic change: both convergence and integration among previous silos (some libraries are museums, galleries and archives, etc.); and dispersal and interconnectivity through digital networks, where the distinction between official and informal repositories is blurred. The emergence of the Internet - as technological metaphor for, and engine of, the knowledge/network-society - has brought with it a burgeoning growth of vernacular archives, folksonomies, fan-sites, and search capabilities (see Castells \& Cardoso 2006). It has massively expanded the range of searchable data and eroded the preeminence of trained experts, who are no longer the sole guarantors of authenticity, objectivity, taste and value - or chief gatekeepers of the form, content, classification and mode of presentation of archived objects. To put it another way, the context in which we can explore strategies for popularising history is one born of a general shift in relations between 'addresser' and 'addressee' in mediated modernity (Lucy 2001; Hartley 1982). The strong asymmetry of the era of mass media between producer (public, institutional, expert; active agency) and consumer (private, family, amateur; passive agency) is rebalancing, such that the audience/consumer is reconfigured into the user/producer of interactive media. Agency is reconceptualised as both intersubjective and mediated - a function of social networks and not individual will. 
Scholars within heritage studies and professionals in the GLAM sector have responded in various ways - some conservatively, as might be expected since conservation is their job; others welcoming a more open environment in which new communities are built around old collections. If one tendency is to order 'fragments of society's knowledge' in a 'highly controlled environment, a closed system' (Parry et al. 2010: 96), the other is ready to embrace the uncontrollable open system of the Web (Cameron \& Kenderdine 2007). Thus, many in museum studies see 'the past' as present- and future-oriented (Kalay et al. 2008). They theorise the audience or consumer (the visitor) as an agent of change, not to be feared as a rampaging bull in the china shop of preservation, but instead to be encouraged, such that users are increasingly playing an active role in creating heritage, by producing the archive, commenting on it and engaging in mash ups that create new 'objects' out of it.

Civic education needs also to take 'data' (like John Curtin) out of the 'cultural freezer' (Parry 2007: 102), and join the 'shared historical authority' movement (Adair et al. 2011), even if that does mean a radical reworking of the concept of authority (to include mash-ups, for instance). In a vastly increased population of user-producers, the 'so what?' question extends from historical figures like Curtin to archives themselves. What are archives for? How do we know? How do they interface with users? Why should users care about the GLAM sector as a whole (never mind civic education), and what might both sides do with each other? For some, more means worse (Schwartz 2012), the democratisation of communication being seen as the death of expert knowledge, while for others, more means MOOCs (massive open online courses) (de Waard et al 2011). For others still, the distribution of productive expertise across a massively broadened social spectrum is a welcome development. 
The creative industries are now digital - produced and consumed in networks and markets where connectivity is as important as creativity, and where expertise is no longer all on the side of providers, but distributed throughout social and digital networks. The extension of digital media, social network markets and digital literacy enables new users to access and manipulate archived materials in hitherto unimagined ways. In this scenario, it is users who lead the kind of experimentation and innovation that stimulates the growth of knowledge, thus shifting responsibility for growth and innovation from expert elites to populations at large.

Of course, people can choose to resist such changes, clinging to the authority of their specialised knowledge in the belief that town and gown cannot mix. But that would condemn what might be inherited or learned from Curtin to the margins of contemporary culture, which in turn would risk oblivion for our hero - a fate that may have befallen him already among the larger population simply by leaving knowledge of him to the experts. If what 'John Curtin' means is decided only by editors of academic journals, curators of official national archives or other specialists, this 'selective tradition' may reduce what's available for citizens' active inheritance to the passive status of cultural sunk capital, possessed by a few, in the name of a population that is dispossessed by the very expertise that seeks to inform it.

When knowledge production changes, information archives change too. As they proliferate across transmedia platforms, both analogue and digital, today's archives diverge to address increasingly specialised uses, whose purposes may or may not overlap with one another. They speciate, as it were, into types whose form is defined by users (and their quest), not by experts (and their collections) - see Fig. 1. 
Fig. 1. The Uses of Archives

\begin{tabular}{|lll|}
\hline Agency (use) & Domain (expertise) & Quest (semiotic/social) \\
\hline Activism & Politics & friends and foes \\
Nation-building & Civics & heroes and histories \\
Inquiry & Science & facts and figures \\
Celebrity, story & Entertainment & fans and fun \\
Public culture & Arts, Education & hortatory heritage \\
Private life & Enterprise, Self-formation & firms and families \\
\hline
\end{tabular}

Archives no longer use a single platform to serve a unitary general public. Like other professional resources they are becoming integrated into a larger creative sector, where private enterprise and the public sector coexist, sometimes uneasily. Much of what would once have been regarded as national heritage - photojournalism is a very good example (Hartley 2007) - has been privatised into global-corporate archives, e.g. Getty Images or Newspix, where access is restricted by copyright and price, not granted by citizenship.

Yet the set of ongoing technological transformations that we call the Internet is also changing the very idea of what an archive can be (Hartley 2012: chapter $7^{\text {'The }}$ Probability Archive'). In the era of digital technologies and globalised culture, it is no longer clear what constitutes an archive (and who says so); or how a given repository of materials can be revivified into active knowledge among a widely distributed and multivalent population of both users (who are also informal collectors and curators) and objects (which appear and disappear). Some conceptions of the Internet offer a seductive image of unlimited archival potential, replete with ideals of comprehensive storage and eternal repositories. But already the logics of user co-creation, media convergence and divergence, and social networking are producing new kinds of flux, 
fragility and ephemerality (Briggs 2010). Meanwhile, old press clippings, television footage and radio recordings - the very stuff of the twentieth-century public record are as likely to be uploaded by ordinary citizens to YouTube and Tumblr, for the purpose of sharing with like-minded friends, as they are to be donated to cultural institutions like the National Film and Sound Archives for the purpose of preserving national heritage. Digitally native archives like YouTube or Flickr, even the World Wide Web itself, offer ever-changing collections: inconceivable rates of growth combined with unpredictable deletions. Their content is supplied by an unorganised, disparate population of users, and platforms are managed according to commercial goals and operational efficiencies rather than heritage-minded ideals of cultural preservation. Such archives promise the probability that something like the soughtafter material will be found (often in exuberant quantity), but cannot guarantee the authenticity or essence of a given object (Hartley 2012).

\section{The User as Ignoramus?}

What kinds of meaning can be made from such uncertain archives of historical record? What kinds of uses can educational, heritage or other professionals make of these unruly archival practices for the purpose of furthering the meanings of an historical figure, such as John Curtin?

Anyone thinking that Curtin's meaningfulness is safe would be wise to think again. We were curious to learn what people (especially young people) might know about him at the University that bears his name, and persuaded a colleague to hold a short quiz among undergraduates to find out. We stress that our straw poll was not intended as a formal survey - official research involving humans as participants, requiring 
ethical clearance - but rather as a preliminary fact-finding exercise among co-citizens. About half of the respondents were Australian; the rest came from Singapore, Malaysia, South Africa, UK, Afghanistan, Brunei, Chile, China, Indonesia, Ireland, Mauritius, South Korea, Sweden, USA or 'Blank'.

What did we discover from this informal quiz of about 65 undergraduates from a variety of courses? First, the good news: 89 per cent had 'heard the name' of John Curtin. Now, the not-so-good news. When asked 'what does he mean to you?' only just over a third knew that he was a former Australian prime minister. A further third thought he had something to do with education (as founder of the university or the eponymous school in Fremantle). The rest - just under a third - thought he was involved in volunteering, philanthropy, or 'leadership equipping'; or that what John Curtin meant to them was: 'Not much'; 'not too sure'; 'does not mean anything'.

One can't draw conclusions from data like these, but perhaps they indicate the mismatch between what 'is known' about Curtin and what people do know, in a place where his name is on daily display, backed up by considerable and admirable resources (buildings, archives, events, rhetoric). That mismatch, between formal knowledge and popular culture, is the traditional locus of cultural and media studies. For many years, some of us have been trying to persuade others, including fellow scholars, that this should not be construed as a difference between 'truth' and 'ignorance'. The point rather, as Richard Hoggart put it (1957: 281), is that 'there are other ways of being in the truth'. People make their own culture, with resources to hand. If they're not using your resources, what are they using, and what values does this express? 
Instead of asking our students about things they don't know, and feeling a pang of Howardian horror as a result, perhaps we should ask them about things they do know, and put John Curtin into that context. So instead of asking "what do you know about John Curtin?' one might ask the following: How do you make your own 'DIY' John Curtin? What can this tell us about him - and about ourselves? Without the material evidence collected in archives, the powerful idea of heritage can have little hold in the public imagination; yet it seems that only specialist historians and political scientists actually use national archives. Of course, educators involved in the distribution of knowledge bring parties of doubtless dutiful school students to visit GLAM institutions, which routinely provide suitable packages and activities for young visitors. But this kind of 'show and tell' procedure doesn't necessarily engage the 'born digital' generation directly, for instance via the apps and platforms they use in other parts of their lives - in their interactions with friends, fantasy characters, movies, games, associated fan-based creative practices, etc. (Jenkins 2006; Banks 2013; Palfrey \& Gasser 2010).

The problem to be addressed, then, has to do with public uses of national archives and other GLAM agencies, based on a reconceptualisation of the public as user, rather than maintaining the traditional focus on the repository itself. How can archival materials communicate to non-specialist users in the digital age, especially younger people? How can they be recast to work with social learning, peer-to-peer style, and with 'learning by doing' in a digital milieu? How might such activity be integrated with the goals of civic education, broadening popular understanding and support for the institutions of democracy? Most immediately, how can civic education link up 
with the DIY ethic of digital culture, where users make rather than consume meanings?

\section{'DIY John Curtin': User-Generated Civic Education}

These questions broach others, about the nature of archiving as a specialist practice. What kinds of archival, exhibition and access practices are appropriate to user-led digital networks? How do existing archives interface with the Internet? What possibilities do digital media open for fostering 'active inheritance'? And how may professional archivists and curators learn from their users, including non-specialist members of the public?

Public access to archival collections is limited by an archive's physical location, which may be at a considerable distance from large sections of the public (the Curtin archive is held mostly in Canberra and Perth, for example) and by the ways in which materials are stored and arranged for use by specialists. Usability can be enhanced through digitising disparate component parts, so that visitors to one place have access to resources elsewhere. Digitisation of materials does not spell the end of physical heritage institutions and historical exhibitions, however, because social learning thrives in the context of physical co-location. New forms of media and mobile technology don't supplant but supplement existing forms, reconfiguring the familiar and making 'old' technologies 'new' again. Hence, virtual visits to heritage collections, for example, may encourage actual excursions to heritage institutions, as well as driving the demand for access to their collections to be opened for previously undreamt uses. 
Digital and online technologies may hold out the promise of overcoming geographical barriers to access, but that simple shift from the physical to the virtual also runs the risk of re-establishing the institutional barriers that have confined archives to specialist use. Here the question of interface or frame is crucial. The frame enables or prohibits, channels or directs access to archival materials (Briggs 2010). If, therefore (echoing McLuhan), the frame $i$ s the message, then the otherwise mute search fields foregrounded by existing online digital repositories all too frequently tell the story of specialist research. Yet general users don't 'search'; they surf. Just as visitors to the Australian War Memorial may gain more pleasure and knowledge from the dioramas (story) than the original artefacts (repository), so may users interact with online archives unencumbered by expert purposes. Non-specialist users don't necessarily have an advance idea of what to search for, and so for them the outcomes of research are truly 'findings' (Halavais 2008).

So: how might the implications of the transformations discussed here be seized and utilised in the context of history, heritage and civic education? In Curtin's case, archival materials can be used to locate him in place, time and meaningfulness, by, for instance:

- Constructing a widening sense of place:

$$
\begin{aligned}
& \text { Cottesloe (home ... and Elsie) }{ }^{11} \\
& \rightarrow \text { Fremantle (seat) }^{12} \\
& \rightarrow \text { Western Australia } \\
& \rightarrow \text { Australia } \\
& \\
& \rightarrow \text { The Allies. }^{15}
\end{aligned}
$$


- Narrating a story through time, for the purposes of political and civic education - the 'narrative accrual' of an Australian identity (Attwood 1996).

- Drawing lessons for the present and future, which may include, among other examples, Keating's 'cooperative regionalism', Lowy's 'muscular approach to our civic life', or Howard's 'self-belief in Western civilisation'.

But what 'John Curtin' means will result from active archival selection, both professional and amateur. Once digitised (many already are), heritage collections become interactive resources for non-specialist users to engage with in ways that don't necessarily conform to old models of instruction and knowledge dissemination. Online platforms - understood not just as a set of technologies, but as a repertoire of cultural skills and practices - provide citizens with the capacity to follow their interests and connections, while promoting interactive, user-created approaches to archival materials.

Bringing Curtin to greater public attention in a competitive and sometimes conflictladen environment requires making archives available for purposes of storytelling, with the user as narrator. The goal might be for users to make their own John Curtin (for the potentially powerful effect of so doing, see Witcomb 2010: 51; Dudley 2012: 4), using archival resources to link self-representation to national (and post-national) heritage (Witcomb 2012). There's scope for users to create do-it-yourself accounts of Curtin's prime-ministership, political career, labour history, journalism, suburban family life and other aspects of his times, against the historical background of Australia's increasing cultural and political integration with the region in which it is located - East Asia and the Pacific, including the USA. 
A suitable model might be the workshop-based digital storytelling movement (Lundby 2009; Hartley \& McWilliam 2009), where expert-facilitated groups of nonprofessionals learn the skills, techniques and potential of digital self-publishing by making their own digital stories in a supportive tutorial environment. Facilitated digital storytelling workshops can be organised for a variety of user-types, where participants are able to use the archive to craft their own story about their own John Curtin.

It transpires that DIY use of archival resources is not just the sign of the amateur; it's also the modus operandi of professional artists and storytellers. In this sense, all representations of Curtin, even apparently original works, may be both DIY and archivally mediated: they are all active interpretations. For instance, a new statue of Curtin was unveiled in Fremantle in 2005, to widespread and continuing criticism, ${ }^{16}$ although the artists have posted a gallery of 'historic references' to show how they 'quoted' archival photographs in the modeling of the figure, its stance and expression. ${ }^{17}$ Another new statue of Curtin, with his Treasurer Ben Chifley, was unveiled in Canberra in 2011 by PM Julia Gillard (City News 2012). This sculpture is based on just one press photograph, and is erected in the very place where that photo was taken, literally returning a press archive to the physical public domain.

Both of these works provoke the question: could you do better - or differently? What would your John Curtin look like, and why? Going a step further, and given the transmedia potential of digital works, there's no need to confine DIY John Curtin to narrative or statuary form. Depending on participants' skills and interests, and on 
what materials are sourced from the archive, possibilities for new ways of representing Curtin may be developed from many contexts, including the following:

- Indigenous people's stories - Indigenous Australians faced discrimination in the military during World War II (Riseman 2012), but Curtin's government extended welfare rights (maternity benefits and pensions) to Aborigines in 1942-43. ${ }^{18}$ What story would an Indigenous workshop tell about Curtin?

- 'Radical Knitting' - a movement whose primary aim, according to the its online manifesto, is to enable 'political discussion with random strangers': 'you'll be amazed how many people come up to ask what it is that you're knitting'. Remembering that Curtin himself used journalism for the same end, perhaps a knitted John Curtin (as distinct from the bronze ones) can be imagined ${ }^{19}$

- A crowdsourced photographic gallery (e.g. on Flickr or Instagram), bringing all the world's 'John Curtin' monuments together. So far we've found quite a few in Fremantle (Fig. 2), Cottesloe (Fig. 3) and Canberra (City News 2012). There is a block of 'John Curtin Flats' on Wollongong beachfront (Fig. 4), as well a play about him, The Fremantle Candidate (Fig. 5)

- Audio-visual production - if school students can stage a musical rendition of the Swan River, why not one on John Curtin (especially by John Curtin College, Fremantle) $?^{20}$

- 3D-printing apps - these allow users to copy existing versions or designs and to print their own John Curtin sculpture 'at home'. ${ }^{21}$

- Talking of homes, you can stay in Curtin's, at Jarrad Street, Cottesloe, so there's a DIY tourist John Curtin. Interviews with holidaymakers who 
ventured the requisite $\$ 250$ per night (minimum of seven nights) may well be instructive. $^{22}$

- Thence - why not? - a digital diorama (Young 2004). ${ }^{23}$

Insert Figs 2-5 about here:

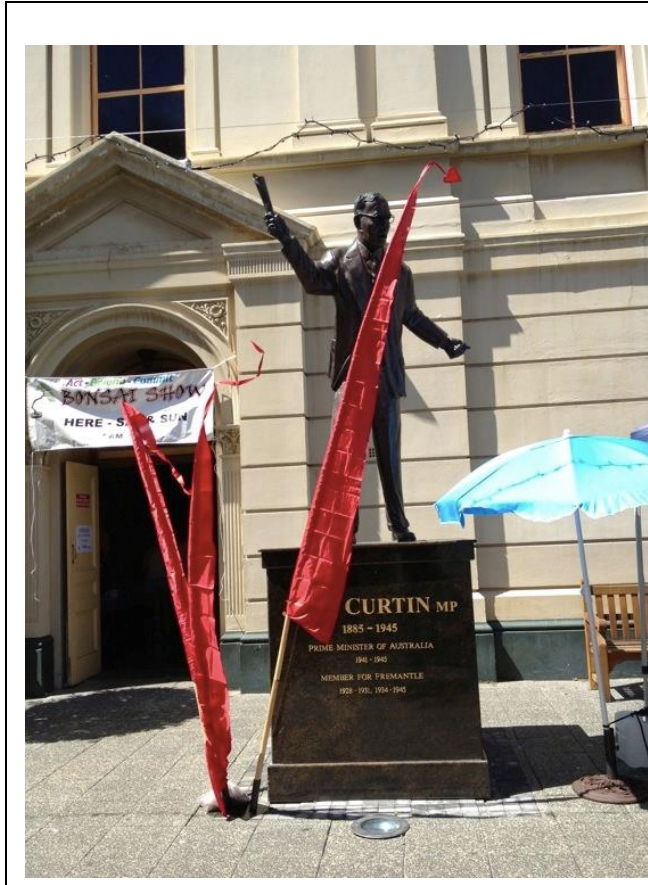

Fig. 2: Curtin in Fremantle (orator)

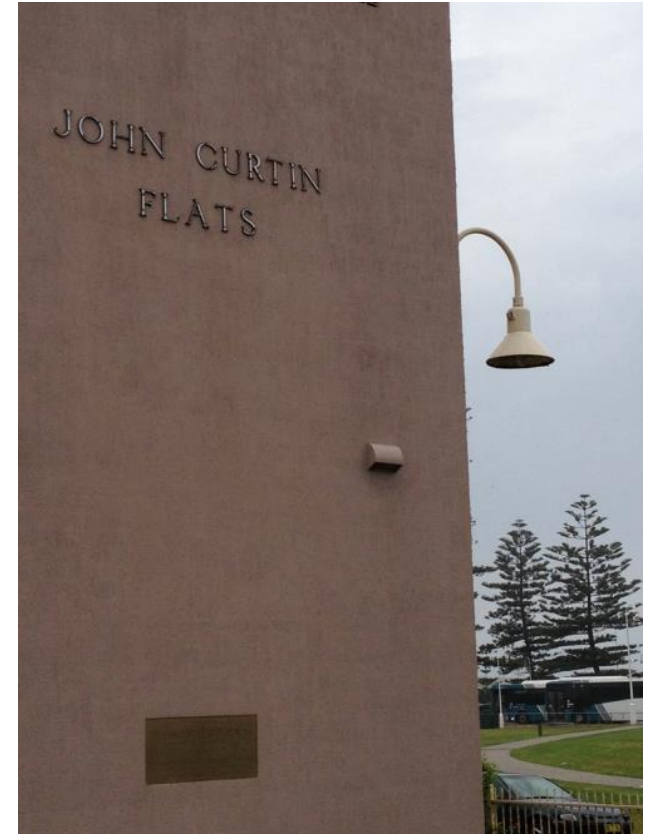

Fig. 4: Curtin in Wollongong (flats)

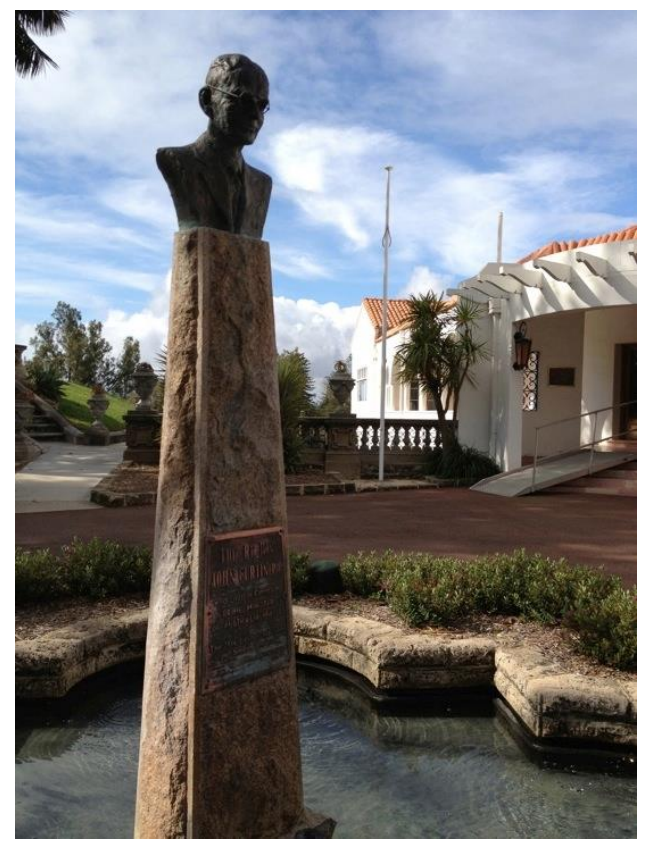

Fig. 3: Curtin in Cottesloe (figurehead)

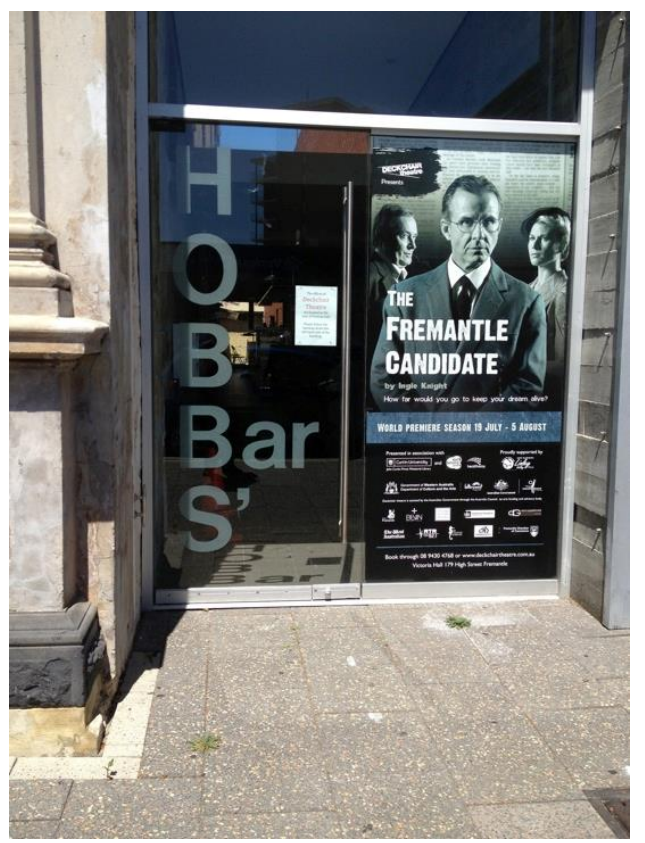

Fig. 5: Curtin on stage (play)

Pictures: J. Hartley 
If these activities seem arbitrary, surely that's the point. For this approach, premised on changing conditions of knowledge production, recognises that non-specialists, far from being ignorant and in need of education, possess their own distributed expertise. Popular interests and practices are the basis from which a new public meaningfulness for John Curtin might emerge, and, in turn, be collected. Civic education and cultural exhibition flow in more than one direction - not just from heritage professional to everyday citizen, but also back again. DIY Curtins have the potential to collect and showcase the cultures of today as much as the events of yesterday, jumping the divide between 'residual' and 'emergent' culture.

\section{Conclusion: DIY Civic Education}

Archivists, educators, curators and heritage/citizenship advocates alike may find themselves learning from users something about what the past means now for people who are new to it. The apparent randomness of their choices is information-rich and meaningful. Expertise is needed to facilitate and understand such plenitude, not to police or scold it.

Citizenship is not quite what it used to be, and neither are the means by which we may interact as members of a citizenry or engage with a past. In a world of social media and networking, and of global popular culture and multi-cultural interests, who John Curtin 'is' becomes a problem for many:

- The nation - citizens at large: potential friends;

- Advocates - for national history and nation-building: myth-makers;

- Professional archivists - object specialists;

- Media analysts and designers - user specialists; 
- Educators - knowledge-distributors and facilitators of social learning by citizens: storytellers.

To approach a better understanding of how the growth of knowledge actually works across demographic, temporal, cultural and social-network boundaries, we need to engage with how communication technologies (archives, design) and user-led innovation intersect with civic education, history and national identity in the digital age. This doesn't mean - far from it - having to shun the past. Indeed, if there's a lesson to be drawn from all of this, it derives no less from active engagement with the past than with the present: the future of national heritage lies not in the injunction that it's good for you, but in the knowledge that everyone, expert or user, is a sucker for dioramas. Which gives us an idea for that 'digital laboratory' space at Curtin University....

\section{References}

Adair, B., B. Filene \& L. Koloski, eds. (2011) Letting Go? Sharing Historical Authority in a User-Generated World, Philadelphia: Pew Center for Arts and Heritage.

Anderson, B. (1991) Imagined Communities, 2nd edn, London: Verso.

Attwood, B. (1996) 'Mabo, Australia and an end of history', in B. Attwood, ed., In the Age of Mabo: History, Aborigines, and Australia, Sydney: Allen \& Unwin, $100-116$.

Banks, J. (2013) Co-Creating Videogames, London: Bloomsbury Academic.

Briggs, R. (2010) 'Silent television: a virtual history of voice and voicelessness in divergent media', CTheory: http://ctheory.net/articles.aspx?id=660 
Cameron, F. \& S. Kenderdine, eds. (2007) Theorizing Digital Cultural Heritage: A Critical Discourse, Cambridge, MA: MIT Press.

Castells, M. \& Cardosa, G., eds. (2006) The Network Society: From Knowledge to Policy, Washington, DC: Johns Hopkins Center for Transatlantic Relations.

City News (2012) 'New Sculpture attracts PM', 16 September. Canberra: http://citynews.com.au/2011/new-sculpture-attracts-pm/

Curtin, J. (1941) 'The task ahead' [First published in The Herald (Melbourne), 27 December 1941]. Online: http://john.curtin.edu.au/pmportal/text/00468.html.

Derrida, J. (1994) Specters of Marx: The State of the Debt, the Work of Mourning, and the New International, trans. Peggy Kamuf, New York and London: Routledge.

Dudley, S. (2012) Materiality Matters: Experiencing the Displayed Object. Working Papers in Museum Studies, No 6. Ann Arbor: University of Michigan: http://ummsp.lsa.umich.edu/files2/8 dudley 2012.pdf.

Dutt, R. Palme (1936) World Politics 1918-1936, London: Victor Gollancz.

Greer, G. (2001) 'Watch with Brother.' The Observer, 24 June: www.guardian.co.uk/theobserver/2001/jun/24/features.review7.

Halavais, A. (2008) Search Engine Society, Cambridge: Polity Press.

Hartley, J. (1982) Understanding News, London: Methuen.

Hartley, J. (1992) The Politics of Pictures: The Creation of the Public in the Age of Popular Media, London: Routledge.

Hartley, J. (1996) Popular Reality: Journalism, Modernity, Popular Culture, London: Arnold (now Bloomsbury).

Hartley, J. (2007) 'Documenting Kate Moss: fashion photography and the persistence of photojournalism', Journalism Studies 8:4, 555-65. 
Hartley, J. (2012) Digital Futures for Cultural and Media Studies, Malden MA and Oxford: Wiley-Blackwell.

Hartley, J. \& J. Green (2006) 'The public sphere on the beach.' European Journal of Cultural Studies, 9:3, 341-62.

Hartley, J. \& K. McWilliam, eds. (2009) Story Circle: Digital Storytelling Around the World, Malden, MA and Oxford, UK: Wiley-Blackwell.

Hebdige, D. (1989) 'After the Masses'. In S. Hall and M. Jacques, eds., New Times: The Changing Face of Politics in the 1990s. London: Lawrence \& Wishart, 7693.

Hewitt, T. (1984) 'Diorama Presentation', Journal of the Australian War Memorial 5, 35.

Hicks, D. (2010) Guantanamo: My Journey, Melbourne and Sydney: Random House Australia.

Hoggart, R. (1957) The Uses of Literacy: Aspects of Working-Class Life, London, Chatto \& Windus.

Howard, J. (2012) Sir Paul Hasluck Foundation Inaugural Lecture, University of Western Australia, 27 September. Accessible at: http://resources.news.com.au/files/2012/09/27/1226482/801957-sir-paulhasluck-foundation-inaugural-lecture.pdf

Jenkins, H. (2006) Convergence Culture, New York: New York University Press.

Kalay, Y., T. Kvan \& J. Affleck, eds. (2008) New Heritage: New Media and Cultural Heritage, London: Routledge.

Keating, P.J. (2009) 'Australia and Asia and the New Order after the Financial Crisis', $11^{\text {th }}$ Anniversary Lecture, Curtin University, 2 July: http://john.curtin.edu.au/events/speeches/keating2009.html 
Lowy, F. (2012) 'Inaugural Australian Multicultural Council Lecture', 19 September. Parliament House Canberra: AMC: www.amc.gov.au/speeches/amc-lecturefranklowy.htm.

Lucy, N. (2001) Beyond Semiotics: Text, Culture and Technology, London: Continuum.

Lucy, N. \& S. Mickler (2006) War on Democracy: Conservative Opinion in the Australian Press, Nedlands: UWA Press.

Lundby, K., ed. (2009) Digital Storytelling, Mediatized Stories: Self-Representations in New Media. New York: Peter Lang.

Miller, T. (2006) Cultural Citizenship: Cosmopolitanism, Consumerism and Television in a Neoliberal Age. Philadelphia: Temple University Press.

Palfrey J. \& U. Gasser (2010) Born Digital: Understanding the First Generation of Digital Natives, New York: Basic Books.

Papacharissi, Z. (2010) A Private Sphere: Democracy in a Digital Age, Cambridge: Polity.

Parry, R., ed. (2010) Museums in the Digital Age, London: Routledge.

Parry, R. (2007) Recoding the Museum: Digital Heritage and the Technologies of Change, London: Routledge.

Peters, M. (2004) 'Citizen-consumers, Social markets and the Reform of Public Services', Policy Futures in Education 2:3-4, 621-632.

Riseman, N. (2012) 'Aboriginal diggers and the battle for equality', The Drum, 25 April 2012: www.abc.net.au/unleashed/3971728.html.

Schmitt, C. (2006) The Concept of the Political, trans. G. Schwab, Chicago: University of Chicago Press. 
Schwartz, S. (2012) 'Quantity and quality', Times Higher Education, 6 September. www.timeshighereducation.co.uk/story.asp?storycode $=421043$.

Waard, I. de, S. Abajian et al. (2011) 'Using mLearning and MOOCs to Understand Chaos, Emergence, and Complexity in Education', IRRODL 12:7, November: www.irrodl.org/index.php/irrodl/article/view/1046/2026? $\mathrm{mid}=53$

Watson, P. (2010) The German Genius: Europe's Third Renaissance, The Second Scientific Revolution and the Twentieth Century. London: Simon \& Schuster. Williams, R. (1961) The Long Revolution. Harmondsworth: Penguin.

Winter, J. (2012) 'Museums and the Representation of War', Museum and Society $10: 3,150-63$.

Witcomb, A. (2010) 'Remembering the dead by affecting the living: the case of a miniature model of Treblinka,' In S. Dudley, ed., Museum Materialities: Objects, Engagements, Interpretations, London: Routledge, 39-52.

Witcomb, A. (2012) 'Using souvenirs to rethink how we tell histories of migration: some thoughts.' In S. Dudley, A-J Barnes, J. Binnie, J. Petrov \& J. Walklate, eds., Narrating Objects, Collecting Stories, pp. 36-50, London: Routledge.

Young, R. (2004) 'The Digital Diorama: Reinventing Narrative for New Media'. In: P. Anastasiou \& K. Trist, eds., Image, Text and Sound 2004: The Yet Unseen: Rendering Stories. Melbourne: RMIT Publishing: www.rebeccayoung.org/html/digital_diorama.htm.

\section{Notes}

\footnotetext{
${ }^{1}$ For information on the AWM dioramas, see: www.awm.gov.au/visit/dioramas/.

${ }^{2}$ See also the many eCitizenship initiatives responding to transformations in 'the ways that citizens interact with others and with government' and corresponding transformations to democracy. E.g.: www.aascu.org/programs/adp/eCitizenship/.
} 
${ }^{3}$ A nationally specific article like this also raises the question of what Curtin might mean to an international readership. One of our reviewers (quoted with permission) recommended some contextualisation, amounting to another kind of 'DIY John Curtin': 'I think it should explain cultural nationalism in Australia, which is basically the Australian Labor Party vs the rest, until John Howard claimed that mantle because Paul Keating had unwisely embraced multiculturalism in public; why the ALP spells Labor without a " $u$ " (the answer is as per Marx: i.e. the real revolution will occur - eventually - in the USA); what Curtin meant as a lapsed Marxist and adopted Western Australian; what it means that he endorsed the 'Brisbane Line', to sacrifice the Northern half the country to an invading Japanese army, but that he is still regarded as a wartime leader (it would have had him excommunicated in the US or UK; and some still consider it treason)'. See also: john.curtin.edu.au/.

${ }^{4}$ See, for instance, 'Calls to curb "birthplace war".' Sky News (Australia), March 6 2013: www.skynews.com.au/topstories/article.aspx?id=851766.

${ }^{5}$ Schmitt was a book-burning Nazi. His 1932 book Der Begriff des Politischen (The Concept of the Political (2006)) theorised fatal conflict as the crucible of national identity; giving scholarly substance to the idea that 'we' can only achieve selfhood in opposition to foes. See Watson (2010) 668-9.

${ }^{6}$ Thus, a search for 'John Curtin' on FB yields little related to the PM, but does connect to 'John Curtin Memes': www.facebook.com/JohnCurtinMemes. This site - presumably referring to the school not the man - is an example of a selforganising association whose purpose is to communicate both community identity and civic values through the mechanism of friendship, combining respect and silliness with peer-to-peer bonding and aspiration.

${ }^{7}$ Howard is reprising an old song here: see Lucy \& Mickler 2006: 'Conclusion (Team Australia)', for a discussion of his address to the National Press Club in Canberra (25 January 2006), on the allegedly parlous state of Australian-history teaching.

${ }^{8}$ The Australian, 28 September 2012: www.theaustralian.com.au/nationalaffairs/opinion/bizarre-history-curriculum-studies-kylie-not-capitalism/storye6frgd0x-1226482887138. For 'Western civilisation', see Dennis Shanahan, 'John Howard revives history wars in attack on Labor curriculum', The Australian, 28 September 2012: www.theaustralian.com.au/national-affairs/education/john- 
howard-revives-history-wars-in-attack-on-labor-curriculum/story-fn59nlz91226482959782.

${ }^{9}$ This sense of international responsibility was revived after a long break by the Rudd/Gillard Labor government's successful bid for a temporary seat on the UN Security Council (October 2012).

${ }^{10}$ Later, in 1949, independence meant attaining citizenship; Australians had hitherto been British 'subjects.' But citizenship was bestowed only on white settlers; it did not extend to Australia's first peoples until after a Referendum in 1967.

${ }^{11}$ See the online archive for Curtin's home: http://john.curtin.edu.au/curtinhouse/. The theme of 'home' raises important issues relating to 'place' - suburbia, domestic life and gender relations in modernising Australia; in particular the role of Elsie Curtin - see: http://john.curtin.edu.au/resources/biography/ecurtin.html.

${ }^{12}$ For Curtin's seat, see: http://john.curtin.edu.au/fremantle/curtin.html. For John Curtin College of the Arts, see: www.jc.wa.edu.au/.

${ }^{13}$ See the archive at Curtin University: http://johncurtingallery.curtin.edu.au/.

${ }^{14}$ See the National Archives of Australia website: http://primeministers.naa.gov.au/primeministers/curtin/; see also the John Curtin School of Medical Research, ANU, Canberra: http://campusmap.anu.edu.au/displaybldg.asp?no=54.

${ }^{15}$ See the archive of Curtin's speeches: http://john.curtin.edu.au/events/speeches/fullilove.html.

${ }^{16}$ For criticism, see: http://theworstofperth.com/2007/11/25/short-arm-syndrome/; and www.publicartaroundtheworld.com/John Curtin Statue.html. For other memorials to Curtin around Australia, see the John Curtin Prime Ministerial Library website at Curtin University: http://john.curtin.edu.au/resources/jcmemory.html.

${ }^{17}$ See the Smith Sculptors website: www.smithsculptors.com/John_Curtin_Memorial_Sculpture_Historic_References. $\underline{\mathrm{html}}$

${ }^{18}$ See Curtin's election speech for 26 July 1943: http://electionspeeches.moadoph.gov.au/speeches/1943-john-curtin.

${ }^{19}$ Radical Knitting manifesto: www.ms.unimelb.edu.au/ paul/radical.html. 
20 'Our Gifted and Talented dance and ballet students' celebrate 'the creation, history and diversity of one of our State's iconic treasures, the Swan River': www.jc.wa.edu.au/Community/Events/180.aspx.

${ }^{21}$ Museums already use 3D techniques allowing visitors to 'make their own' sculptures from collections - see Gizmodo: http://gizmodo.com/5917341/you-can$\underline{3 d-p r i n t-s c a l e-v e r s i o n s-o f-f a m o u s-m u s e u m-s t a t u e s-f o r-y o u r-h o m e . ~ F o r ~ a n ~ a p p ~ t o ~}$ do it with, try Autodesk: www.123dapp.com/catch. There's also a market in DIY 3D sculpting of more demotic objects - visit, for instance, the Reprap Central website: www.reprapcentral.com/Digital-Designs/.

${ }^{22}$ For the homestay, see: www.cbhstays.com.au/TheCurtinFamilyHome.html; and the National Trust website: www.curtinfamilyhome.com.au/index.php.

${ }^{23}$ For a digital diorama DIY tutorial, see: www.shutterstock.com/blog/2012/01/photoshop-tutorial-digital-diorama/. 